\title{
Ortaokul Öğrencilerinin Pandemi Sürecindeki Fiziksel Aktivite Tutumu ve Stresle Başa Çıkma Durumlarının Değerlendirilmesi
}

\author{
Evaluation of Secondary School Students' Attitude to Physical Activity and Their Coping With Stress in the \\ Pandemic Process
}

\author{
Tuğba AYDIN YILDIRIM ${ }^{1}$, Nevin ONAN ${ }^{2}$
}

\begin{abstract}
ÖZ
$\mathrm{Bu}$ çalışma, ortaokul öğrencilerinin pandemi sürecindeki fiziksel aktivite tutumu ve stresle başa çıkma durumlarının değerlendirilmesi amacıyla yapılmıştır. Tanımlayıcı tipte olan bu çalışma 99 ortaokul öğrencisi ile tamamlanmıştır. Çalışmada katılımcıların sosyodemografik özelliklerini (yaş, cinsiyet, sınıf düzeyi vb.) sorgulayan veri formu, Ortaokul Öğrencileri için Fiziksel Aktivite Tutum Ölçeği (FATÖ) ve Çocuklarda Stresle Başa Çıkma Ölçeği (ÇSBÖ) kullanılmıştır. Veriler, tanımlayıcı istatistikler (yüzde, ortalama vb.), Mann Whitney U testi, Kruskal Wallis H testi ve Spearman's korelasyon testi ile analiz edilmiştir. Elde edilen verilere göre, öğrencilerin FATÖ puan ortalamasının $96,26 \pm 15,37$ olduğu bulunmuştur. ÇSBÖ alt boyut puan ortalamalarına bakıldığında, en yüksek puan ortalamasının diş yardım arama alt boyutunda $(13,82 \pm 3,11)$ olduğu, öke/saldırganlık alt boyut puan ortalamasının ise en düşük puan ortalamasına $(8,21 \pm 2,67)$ sahip olduğu saptanmıştır. FATÖ genel toplam ve alt boyutları ile ÇSBÖ alt boyutları arasında istatistiksel olarak anlamlı ilişkiler belirlenmiştir. Ortaokul öğrencilerinin pandemi döneminde, olumlu fiziksel aktivite tutumunun ve egzersiz planlamalarının stresle başa çıkma süreçlerine katk1 sağlayacağı düşünülmektedir. Sınava girecek 8. sınıf öğrencileri için bu planlamaların önemi ayrıca vurgulanmaktadır.
\end{abstract}

Anahtar Kelimeler: Fiziksel aktivite tutumu, Öğrenciler, Pandemi, Stresle başa çıkma

\begin{abstract}
This study was conducted to evaluate the physical activity attitudes and coping with stress of secondary school students during the pandemic process. This descriptive study was completed with 99 secondary school students. In the study, a data form questioning the sociodemographic characteristics of the participants (age, gender, grade level, etc.), Physical Activity Attitude Scale for Secondary School Students and Coping with Stress Scale for Children were used. Data were analyzed with descriptive statistics (percentage, mean, etc.), Mann Whitney U test, Kruskal Wallis $\mathrm{H}$ test, and Spearman's correlation test. According to the data obtained, it was found that the students' Physical Activity Attitude Scale for Secondary School Students mean score was $96.26 \pm 15.37$. When the mean scores of the Coping with Stress Scale for Children subdimensions are examined, it has been determined that the highest mean score is in the sub-dimension of seeking help from outside $(13.82 \pm 3.11)$, while the mean score of the anger/aggression sub-dimension has the lowest mean score (8.21 \pm 2.67$)$. Statistically significant correlations were found between Physical Activity Attitude Scale for Secondary School Students grand total and sub-dimensions and Coping with Stress Scale for Children sub-dimensions. It is thought that the positive physical activity attitude of secondary school students and the physical activities to be planned will contribute to the processes of coping with stress. In addition, the importance of these plans for 8th grade students who will take the exam is also emphasized.
\end{abstract}

Keywords: Coping with stress, Pandemic, Physical activity attitude, Students

\footnotetext{
"Araştırmaya başlamadan önce bir üniversitenin girişimsel olmayan etik kurulundan etik kurul izni (sayl: E-77192459-050.99-13656 tarih:03.03.2021) ve çallşmanın ilgili kurumda yapılabilmesi için gerekli kurum izni alınmıştır.

${ }^{1}$ Dr. Öğr. Üyesi, Tuğba AYDIN YILDIRIM, Halk Sağlığı Hemşireliği Anabilim Dalı, Karabük Üniversitesi Sağlık Bilimleri Fakültesi, Hemşirelik Bölümü, tugbaaydin@karabuk.edu.tr, ORCID: 0000-0001-5475-2345

${ }^{2}$ Doç. Dr., Nevin ONAN, Psikiyatri Hemşireliği Anabilim Dalı, Karabük Üniversitesi Sağlık Bilimleri Fakültesi, Hemşirelik Bölümü, nevinonan@karabuk.edu.tr, ORCID: 0000-0002-3688-507X 


\section{GIRIŞ}

Dünya Sağlık Örgütü, insan yaşamında 10-19 yaş aralığını gelişimsel özelliklerin yaşandığ 1 ergenlik dönemi olarak tanımlamıştır. ${ }^{1} \mathrm{Bu}$ yaş aralığı, değişim özellikleri ve gelişme süreçleri göz önünde bulundurulduğunda, yaşamın geri kalan dönemleri üzerindeki etkisi ile en dikkat gösterilmesi gereken dönemlerindendir. $\mathrm{Bu}$ dönemde kazanılan alışkanlıklar, tercih edilen yaşam tarzı ve sağlık davranışları bireyin ileriki yaşlarında, elde edilen kazanımlar ya da kayıplar olarak karşısına çıkmaktadır. ${ }^{2}$ Ergenlik döneminde dönemsel özellikleri nedeni ile strese duyarlılık daha fazladır. Bu sebeple, çocuklara ve gençlere stresle başa çıkma becerisinin kazandırılması ve fiziksel aktivitenin bir alışkanlık haline getirilmesi sağlıklı yetişkinlerin yer aldığı sağlıklı toplumların oluşturulmasında büyük önem taşımaktadır. ${ }^{3,4}$ Fiziksel aktivitenin sağlık üzerindeki olumlu etkileri arasında kan basıncı ve insülin kontrolü, trigliserid ve kolesterol seviyelerinin düzenlenmesi vb. sayılabilmektedir. ${ }^{5} \quad$ Ek olarak, fiziksel aktivitenin ruhsal durum, duygusal yönetim, stresle baş etmede de pozitif yönde etki yarattı̆ğ, bazı çalışma bulguları ile ifade edilmektedir. ${ }^{6,7}$

Fiziksel aktivitenin fiziksel ve ruhsal sağlık üzerine olumlu etkilerinin açık bir şekilde ifade edilmesine karşın, özellikle son y1llarda ergen gruplarda hareketsizleşen yaşam tarzı tercihlerinin benimsendiği bildirilmektedir. ${ }^{8,9} \mathrm{Bu}$ durumun sebepleri arasında internet kullanımının artık daha ulaşılabilir olan telefonlar $\operatorname{aracil} \breve{g ̆}_{1}$ ile gerçekleştirilebilmesi, bu sebeple internette geçirilen sürenin uzaması, sosyal etkileşimin internet ortamında yaşanması ve bundan duyulan haz duygusu gibi durumlar gösterilmektedir. ${ }^{8,9}$ Modern hayatta internette geçen sürenin uzaması fiziksel aktivitede sınırlılığın yanı sira boyun ağrısı gibi fiziksel sağlık sorunlarına, stres ve depresyon yaşama gibi ruhsal sağlik sorunlarına da neden olmaktadır. ${ }^{10,11}$
Hareketsizliğe eğilim ve yol açtığ sorunlar günümüzde tüm dünyayı etkisi altına almış olan covid-19 pandemi sürecinde daha da kolaylaşmıştır. 2019 yılının sonlarında Çin'in Wuhan kentinde ortaya çıkan patojenin yapılan çalışmalar ile yeni tip bir koronavirüs olarak tanımlanması ve damlacık yoluyla bulaş yaptığının açıklanması ile tüm dünya ülkeleri alarma geçmiştir. Dünya Sağlık Örgütü, hızlı bulaşması, kısa sürede yaşamın devamlılığında ciddi riskler oluşturması ve yeni bir virüs olması sebepleri ile 11 Mart 2020 tarihinde pandemi ilan etmiştir. $\mathrm{Bu}$ tarihten itibaren tüm dünya ülkeleri kendi sağlık bakım sistemleri çerçevesinde bir dizi önlem almıştır. ${ }^{12} \mathrm{Bu}$ önlemlerden genelde kabul gören ve uygulanan önlemlerden ikisi sosyal mesafenin korunması ve evlerde kalma çağrısıdır. ${ }^{13}$ Uzun süre evde kalma, yaşı1 gruplarla sosyal etkileşim kuramama her yaş grubunu etkilemekle birlikte ergen grubu da etkilemiştir. ${ }^{14}$ Uzun süre evde kalan ergenlerde, izole bir yaşam fiziksel aktivitenin sınırlanmasının yanında stres düzeyindeki artma eğiliminin de artabileceği anlamına gelmektedir. ${ }^{14} \mathrm{Bu}$ süreçte stres ile etkin baş edememe, duyarlılığg olan bireylerde tükenmişlik duygusuna ve bu duygunun getireceği olumsuzlukların yaşanmasına yol açabilmektedir. Stres yönetiminde önerilen yaklaşımlardan biri de fiziksel aktivitelerde bulunma ve günlük bir rutin haline getirilmesidir. ${ }^{15,16}$ Bunun sebebi fiziksel aktivite ile stres düzeyi arasındaki ilişkiyi ortaya koyan bilimsel çalışmalardır. ${ }^{17,18}$

Covid-19 pandemi sürecinde, ergenlik dönemindeki önemli bir yaş aralığında olan ortaokul öğrencilerinin zorunlu kısıtlamalar nedeni ile yaşayabilecekleri stres düzeyi ve stresle başa çıkmada olumlu etkisi kabul gören fiziksel aktiviteye yönelimleri oldukça önemlidir. $\mathrm{Bu}$ sebeple çocukların kısıtlı koşullarda da olsa fiziksel aktiviteyi rutin yaşamlarına entegre edebilmelerinin fiziksel ve ruhsal sağlığı olumlu etkileyerek katkı 
sağlayacağı düşünülmektedir. Bu konuda rehberlik yapılabilmesi için girişimsel planlamaların öncesinde, pandemi sürecinde bu yaş grubunun stresle başa çıkma ve fiziksel aktivite durumunun, tanımlayıcı çalışmalar ile saptanmasının yol gösterici olabileceği öngörülmektedir. Yapılan çalışmalar incelendiğinde, uluslararası literatürde bazı çalışmaların olduğu görülse de $^{19,20}$, ulusal literatürde covid 19 pandemi sürecinde ortaokul öğrencilerinde fiziksel aktivite ve stresle başa çıkmayı birlikte değerlendiren bir çalışmaya rastlanmamıştır. $\mathrm{Bu}$ bilgiler 1şığında bu çalışma, ortaokul öğrencilerinin pandemi sürecindeki fiziksel aktivite tutumu ve stresle başa çıkma durumlarının değerlendirilmesi amacıyla yapılmıştır. Çalışmada aşağıdaki sorulara yanıt aranmıştır:

- Ortaokul öğrencilerinin pandemi sürecindeki fiziksel aktivite tutumu nasildir?

- Ortaokul öğrencilerinin pandemi sürecindeki stresle başa çıkma durumu nasıldir?

- Öğrencilerin fiziksel aktivite tutumları ve stresle başa çıkma yolları arasında bir ilişki var mıdır?

- Sosyo-demografik değişkenlere göre öğrencilerin fiziksel aktivite tutumları ve stresle başa çıkma durumlarında farklılık var midır?

\section{MATERYAL ve METOT}

\section{Araştırmanın Tipi}

Araştırma tanımlayıcı tipte tasarlanmıştır.

\section{Araştırmanın Yer ve Zamanı}

Araştırma Karabük ilinde yer alan bir özel okulun ortaokul bölümünde MartMayıs 2021 tarihleri arasında yapılmıştır.

\section{Evren ve Örneklem}

Çalışmanın evrenini ilgili ortaokulda öğrenim gören 164 öğrenci oluşturmaktadır. Herhangi bir örneklem seçimine gidilmeyip dahil edilme kriterine uyan herkes çalışmaya davet edilmiştir. Dahil kriterlerine uyan 42 beşinci sınıf, 18 altıncı sınıf, 12 yedinci sınıf ve 27 sekizinci sinıf olmak üzere toplam 99 öğrenci ile çalışma tamamlanmıştır.

\section{Dahil Edilme Kriterleri}

- İlgili okulda kayıtlı ortaokul öğrencisi olmak,

- Herhangi bir psikiyatrik tanı almamış olmak

- Herhangi bir psikiyatrik ilaç kullanmiyor olmak

- Veli onamı alınmış olması,

- Çalışmaya katılmaya gönüllü olmak

\section{Dışlama Kriterleri}

- Herhangi bir psikiyatrik tanı almış olmak

- Herhangi bir psikiyatrik ilaç kullanıyor olmak

- Velinin çalışmaya katılmayı reddetmesi

- Veri toplama formlarını eksik doldurmak

\section{Veri Toplama Yöntemi}

Veri toplama araçları çalışma hakkında bilgi verildikten sonra ilgili okulun rehber öğretmeni iş birliğinde katılımcılara ulaştırılmış ve verip-alma yoluyla veriler toplanmıştır. Bu aşamada veli onamı da alınmıştır.

\section{Veri Toplama Araçları}

Veriler, araştırmacılar tarafından hazırlanan öğrencilerin sosyodemografik özelliklerini (yaş, genel sağlık durumu, günlük yaşamı vb.) sorgulayan kişisel veri formu, "Ortaokul Öğrencileri için Fiziksel Aktivite Tutum Ölçeği (FATÖ)" ve "Çocuklarda Stresle Başa Çıkma Ölçeği (ÇSBÖ)" ile toplanmıştır. 
Ortaokul Öğrencileri için Fiziksel Aktivite Tutum Ölçeği: Ölçek, Yıldızer vd. tarafından 2019 yılında geliştirilmiştir. ${ }^{21}$ 5'li likert tipindeki ölçme aracında cevaplar şu şekildedir: "1=Kesinlikle Katılmıyorum", "2=Katılmiyorum", "3=Kararsizım", "4=Kat1liyorum", "5=Kesinlikle Katılıyorum". Yüksek puan yüksek tutumu ifade ederken, düşük puan ise düşük tutumu göstermektedir. Ölçek, 5 alt boyut ve 25 maddeden oluşmaktadır. Alt boyutları: Sevgi (5 madde), İsteklilik (7 madde), Fayda (5 madde), Sosyalleşme (4 madde) ve Öz Güven (4 madde) Alt boyutların Cronbach Alfa katsayısına göre hesaplanan güvenirlik değerleri İsteklilik için 0,85 , Sevgi için 0,83 , Sosyalleşme için 0,82, Fayda için 0,75, Öz Güven için 0,70 ve tüm maddeler birlikte analiz edildiğinde ise güvenirlik katsayısı 0,91 olarak bildirilmektedir.

Çocuklarda Stresle Başa Çıkma Ölçeği (ÇSBÖ): Özbay vd. (2009) tarafindan geliştirilen her biri 5 maddeyi içeren 6 faktörden (Öfke/Saldırganlık, Dış Yardım Arama, Duygusal Kaçma, Eylemsel Kaçma, Kabul/Bilişsel yeniden yapılandırma, Aktif Planlama) toplam 30 maddeden oluşmaktadır. ${ }^{22}$ Likert tipinde olan ölçek 1 (hiçbir zaman) ile 4 (her zaman) aralığında puanlanmaktadır. Ölçeğe ait alt boyutların Cronbach Alfa güvenirlik katsayıları 0,60 ile 0,74 arasinda bildirilmektedir.

\section{Verilerin Analizi}

Verilerin analizinde, tanımlayıcı istatistiklerden (yüzde, ortalama, standart sapma, minimum ve maksimum değerler) yararlanılmıştır. Çocukların BKİ persentil değerleri Neyzi ve ark. tarafindan hazırlanan Türk çocukları için BKİ referans tablosu kullanılarak değerlendirilmiş, Amerikan Pediatri Akademisi referans değerleri baz alınarak kategorize edilmiştir. ${ }^{23}$

Verilerin Kolmogorov Smirnow testine göre $(p<0,05)$ normal dağılıma uygun olmadığ 1 belirlenmiş ve veriler nonparametrik testlerle (Mann Whitney U testi, Kruskal wallis $\mathrm{H}$ testi) değerlendirilmiştir. Ölçeklerin birbirleri ve bazı değişkenler ile ilişkisinin değerlendirilmesinde spearman korelasyon testi uygulanmıştır. Anlamlılık düzeyi olarak $\mathrm{p}<0,05$ kabul edilmiştir.

\section{Araştırmanın Etik Yönü}

Araştırmaya başlamadan önce bir üniversitenin girişimsel olmayan etik kurulundan etik kurul izni (say1: E77192459-050.99-13656 tarih:03.03.2021) ve çalışmanın planlanan kurumda yapılabilmesi için gerekli kurum izni alınmıştır. Öğrencilere ve velilerine çalışmanın amacı araştırmacı tarafından bildirilip elde edilen verilerin sadece bu araştırma için kullanılacağı açıklanmış ve öğrencilerin velilerinden bilgilendirilmiş olur alınmış̧ır. Araştırmada kullanılacak ölçekleri geliştiren uzman kişilerden e-mail yolu ile kullanım izni alınmıştır. Helsinki Bildirgesi ilkelerine bağlı kalınmıştır.

\section{BULGULAR ve TARTIŞMA}

Çalışmaya katılan 99 ortaokul öğrencisinin \%58,6'sının erkek, yaş ortalamasının $11,90 \pm 1,27$ ve beden kütle indeksi (BKİ- $\mathrm{kg} / \mathrm{m}^{2}$ ) ortalamasının 21 $\pm 3,93$ olduğu belirlendi.

Öğrencilerin FATÖ toplam puan ortalamas1 96,26 $\pm 15,37$ olarak hesapland1 ve alt boyut puan ortalamaları Tablo 1'de sunuldu. Öğrencilerin ÇSBÖ alt boyut puan ortalamalarında en yüksek puan ortalamasının dış yardım arama alt boyutunda $(13,82 \pm 3,11)$ olduğu ve bunu aktif planlama/problem çözme alt boyutunun $(12,64 \pm 2,81)$ izlediği, öke/saldırganlık alt boyut puan ortalamasının ise en düşük puan ortalamasına $(8,21 \pm 2,67)$ sahip olduğu saptand1 (Tablo 1). Bu bulgulara göre, öğrencilerin kayg1 ve stresin yüksek olduğu pandemi döneminde dışarıdan bir destek arama, sorunlar karşısında aktif planlama ve 
problem çözme becerilerini kullanma gibi etkin baş etme becerilerini daha fazla, stres karşısında öfkeli ve saldırgan davranışlara yönelme gibi etkin olmayan baş etme yöntemlerini daha az kullandıkları ve dolayısı ile stresle etkin olarak başa çıktıkları söylenebilir. ${ }^{24,25}$

Tablo 1. FATÖ, ÇSBÖ Alt Boyutları Puan Ortalamalarının Dağılımı

\begin{tabular}{rrrrrr}
\hline & \multicolumn{1}{c}{$\begin{array}{c}\text { Madde } \\
\text { sayısı }\end{array}$} & $\begin{array}{c}\text { Puan } \\
\text { Aralığı }\end{array}$ & Ortalama (SS) & Min- Max \\
\hline FATÖ ve AIt Boyutlar & & & & & \\
\hline & Genel Toplam & 25 & $25-125$ & $96,26(15,37)$ & $52-123$ \\
& İsteklilik & 7 & $7-35$ & $30,81(4,32)$ & $11-35$ \\
& Sevgi & 5 & $5-25$ & $18,32(3,66)$ & $7-25$ \\
Fayda & 5 & $5-25$ & $17,27(4,46)$ & $6-25$ \\
& Sosyalleşme & 4 & $4-20$ & $15,07(3,79)$ & $4-20$ \\
ÇSBÖ-Alt Boyutlar & Özgüven & 4 & $4-20$ & $14,77(3,94)$ & $4-20$ \\
\hline & & & & & \\
Öke/Saldırganlık & 5 & $5-20$ & $8,21(2,67)$ & $5-16$ \\
Diş Yardım Arama & 5 & $5-20$ & $13,82(3,11)$ & $6-20$ \\
Duygusal Kaçma & 5 & $5-20$ & $11,55(2,65)$ & $6-18$ \\
Kabul/Bilişsel Yeniden Yapılandırma & 5 & $5-20$ & $8,97(2,79)$ & $5-20$ \\
Ektif Planlama/Problem Çözme & 5 & $5-20$ & $10,05(2,29)$ & $5-15$ \\
& 5 & $5-20$ & $12,64(2,81)$ & $7-19$ \\
\hline
\end{tabular}

ÇSBÖ: Çocuklarda Stresle Başa Çıkma Ölçeği, FATÖ: Fiziksel Aktivite Tutum Ölçeği

FATÖ genel toplam puan, isteklilik, fayda, sosyalleşme, özgüven alt boyutları ile ÇSBÖ alt boyutlarından aktif planlama/problem çözme arasında pozitif yönlü, benzer şekilde FATÖ genel toplam puan, isteklilik, fayda, sosyalleşme alt boyutları ile ÇSBÖ dışsal yardım arama alt boyutu arasında da pozitif yönlü bir ilişkinin olduğu belirlendi $(p<0,05)$. Elde edilen bulgular, fiziksel aktivitenin stresle başa çıkmadaki olumlu yönünü vurgular niteliktedir. Stresle etkin baş etme becerisi olan öğrencilerin fiziksel aktiviteye karş1 istekli, özgüvenli olduklarını, fiziksel aktivitenin faydalı olduğu ve sosyalleşmeyi arttırdığ 1 yönünde bir tutum sergilediklerini göstermektedir. Fiziksel aktivitenin stresle başa çıkmada olumlu etkisini gösteren Taş'ın çalışmasında, spor yapan öğrencilerin stres düzeyinin anlamlı olarak daha düşük olduğu ifade edilmektedir. ${ }^{26}$ Stresle başa çıkmada, fiziksel aktivite düzeyinin artırılmasının etkili bir yöntem olduğunu gösteren veriler bulunmaktadır. ${ }^{27}$ Ulusal literatürde, pandemi döneminde fiziksel aktivite tutumu ile stresle başa çıkma durumunu birlikte değerlendiren, korelasyonunu inceleyen bir çalışmaya rastlanmamıştır. $\mathrm{Bu}$ çalışma bulguları bu yönüyle ulusal literatüre katkı sağlamakta ve özgün yanını güçlendirmektedir. Ayrıca, elde edilen verilere göre fiziksel aktivite düzeyinin artırılması ile stresle başa çıkmada kazanım elde edilebileceği düşünülmektedir. Öfke/saldırganlık ve $\mathrm{kabul} /$ bilişsel yeniden yapılandırma ile isteklilik arasında negatif bir ilişki belirlenirken $(r=-0,32$ ve $r=-0,32)$; duygusal kaçma ve eylemsel kaçma ile fiziksel aktivite tutumları arasında istatistiksel olarak anlamlı bir ilişki bulunmamıştır (Tablo 2). 
Tablo 2. FATÖ ve ÇSBÖ Alt Boyutları Arasındaki Korelasyonlar

\begin{tabular}{|c|c|c|c|c|c|c|}
\hline \multirow{3}{*}{ ÇSBÖ } & \multicolumn{6}{|c|}{ FATÖ } \\
\hline & GT & $\dot{\mathrm{I}}$ & $\mathrm{S}$ & $\mathrm{F}$ & $\mathrm{SO}$ & $\ddot{\mathrm{O}}$ \\
\hline & $\mathrm{r}_{\mathrm{s}}$ & $\mathrm{r}_{\mathrm{s}}$ & $\mathrm{r}_{\mathrm{s}}$ & $\mathrm{r}_{\mathrm{s}}$ & $\mathrm{r}_{\mathrm{s}}$ & $\mathrm{r}_{\mathrm{s}}$ \\
\hline Öke/Saldırganlık & $-0,16$ & $-0,32 * *$ & 0,13 & $-0,11$ & $-0,17$ & $-0,15$ \\
\hline Dış Yardım Arama & $0,30 * *$ & $0,22 *$ & 0,18 & $0,28 * *$ & $0,32 * *$ & 0,17 \\
\hline Duygusal Kaçma & 0,08 & $-0,02$ & 0,07 & 0,03 & 0,16 & 0,02 \\
\hline Kabul/Bilişsel Yeniden Yapılandırma & $-0,16$ & $-0,32 * *$ & 0,13 & $-0,11$ & $-0,17$ & $-0,15$ \\
\hline Eylemsel Kaçma & 0,02 & $-0,08$ & 0,12 & 0,04 & 0,06 & $-0,00$ \\
\hline Aktif Planlama/Problem Çözme & $0,33 * *$ & $0,26 * *$ & 0,08 & $0,27 * *$ & $0,38 * *$ & $0,28 * *$ \\
\hline
\end{tabular}

Sınıf değişkenine göre fiziksel aktivite tutumlarında özgüven alt boyutu dişında gruplar arasında anlamlı farklılıklar olduğu ve anlamlılığın beşinci sınıf öğrencilerinin puan ortalamasının yüksek olmasından kaynaklandığ 1 belirlendi $(p<0,05)$. (Tablo 3). Sınıf düzeyi yükseldikçe yani yaşı büyükçe ortaokul öğrencilerinin hareketsizleştiği ve fiziksel aktivite düzeyinin gerilemesi bulgusunu, Çubuk'un çalışması da desteklemektedir. ${ }^{28}$ Elde edilen verilerdeki benzerliğin, örneklemlerin aynı yaş ve okul dönemindeki öğrencilerden oluşması, 8. sınıf ve sonrası sınav dönemi yaklaştıkça öğrencilerin daha çok ders çalışarak hareketsizleşmiş olma ihtimali ile ilişkili olabileceği düşünülmektedir. BKİ persentil gruplamaları açısından öğrencilerin fiziksel aktivite tutumlarında anlamlı bir fark saptanmadi $(p>0,05)$.

Öğrencilerin büyük çoğunluğunun pandemi öncesinde düzenli ya da bazen fiziksel aktivitelerde bulundukları verisi, aynı yaştaki örneklemlerde gerçekleştirilen bazı çalışma verileri ile benzerlik göstermektedir. ${ }^{28,29}$ Çubuk'un ve Birgün ve ark.'nın pandemi öncesinde ortaokul öğrencilerinde yaptıkları çalışmalarında, katılımcıların fiziksel aktiviteye yönelik tutumlarının yüksek olduğu ve çoğunluğunun aktif bir yaşam sürdüğü bildirilmektedir. ${ }^{28,29}$ Pandemi öncesinde düzenli fiziksel aktivite yapan öğrencilerin FATÖ toplam puan, isteklilik, sevgi, fayda ve özgüven alt boyutlarındaki puan ortalamaları fiziksel aktivite yapmayan ve bazen yapan öğrencilerin puan ortalamalarından anlamlı olarak yüksek bulundu $(p<0,05)$. Benzer şekilde, Pandemi döneminde uzaktan eğitime geçilmesiyle birlikte hareketsiz kalma düşüncesine göre FATÖ toplam puan $(p=0,003)$, isteklilik $(p=0,005)$, fayda $(p=0,016)$ ve özgüven $(p=0,008)$ alt boyutlarında gruplar arasında anlamlı farklar olduğu ve anlamlılı̆̆ın hareketsizlik düşüncesine sahip olmayanlar lehine olduğu belirlendi. $\mathrm{Bu}$ çalışmadaki katılımcıların uzaktan eğitim sürecine geçilmesi ile hareketsizleştiklerini ifade etmeleri $(\% 59,6)$, İnce Parpucu ve ark.'nın, ve Lim ve ark.'nın çalışmaları ile desteklenmektedir. ${ }^{30,31}$ Ad1 geçen çalışmalarda, pandemi öncesine göre pandemi sırasında fiziksel aktivite düzeyinin oldukça azaldığı ve bu azalmanın da istatistiksel olarak anlamlı olduğu vurgulanmaktadır. Pandemi sürecinde evde kalma çağrıları ve uzaktan eğitim ile öğrencilerin hareketsizleştiği böylelikle fiziksel aktiviteye ayrılan sürenin de kısaldığı düşünülmektedir. Ek olarak, evinde fiziksel aktivite için herhangi bir alete sahip olan öğrencilerin olmayanlara göre FATÖ toplam puan ve özgüven alt boyutu puan ortalamasının anlamlı olarak daha yüksek olduğu, gün içinde 1-3 saat teknolojik araç kullanan ögrrencilerin dört saatten daha fazla kullananlara göre fiziksel aktivite için daha özgüvenli bir tutum içinde oldukları belirlendi (Tablo 3).

Çalışma bulguları birlikte değerlendirildiğinde; pandemi öncesi 
hareketli bir yaşamı olan, egzersiz yapan, uzaktan eğitim ile hareketsizleşmediğini düşünen, evinde egzersiz için bir spor aleti bulunan, gün içinde ders dişı amaçlarla tablet, telefon gibi teknolojik araçlara daha az zaman ayıran öğrencilerin fiziksel aktiviteye karşı daha olumlu tutum içinde oldukları ve daha faydalı buldukları, aktivite için daha istekli ve özgüvenli oldukları söylenebilir. $\mathrm{Bu}$ bulgular öğrencilerin pandemi öncesi dönemde sahip oldukları egzersiz yapma alışkanlıklarının pandemi sürecinde olumlu etkisini görmüş olabilecekleri, fiziksel aktivite için olumlu tutumda olan öğrencilerin pandemi döneminde hareketsiz kalmadıkları ve evlerindeki spor aletleriyle fiziksel aktiviteye devam ettikleri şeklinde de yorumlanabilir. Fiziksel aktivite düzeyi düşük olan öğrencilerin de pandemi ve uzaktan eğitim ile daha sedanter bir yaşama geçerek tablet gibi teknolojik araçlara daha uzun zaman ayırmış olabilecekleri düşünülmektedir. $\mathrm{Bu}$ değerlendirmeler yapılan diğer çalışmalar ile de benzerlik göstermektedir. ${ }^{28,30-32}$ Literatürde pandemi dönemi ile öncesi dönemde yapılan fiziksel aktivite düzeyini karşılaştıran çalışmalar, iki zaman arasında anlamlı bir fark gösterip pandemi aleyhine bir değişim olduğu bildirilmektedir. $^{30,31} \quad \mathrm{Bu}$ çalışmadaki katılımcıların pandemi süresinde teknolojik araçların kullanımına ayırdıkları süre için ifadeleri ve Lim ve ark.'nın ortaokul öğrencileri ile yaptıkları çalışmalarında elde ettikleri pandemi döneminde ders dişı ekranda geçirilen sürenin anlamlı şekilde yükseldiği verisi, diğer bulgularla benzerlik göstermektedir. ${ }^{31}$ Literatür incelendiğinde fiziksel aktivite düzeyinde ya da tutumunda gerileme ile teknolojik araçlarla geçirilen süre arasında negatif anlamlı ilişki tespit edildiğini bildiren çalışmalar bulunmaktadır. ${ }^{33,34}$ Hareket etmeyen çocukların bu dönemde teknolojik araçlara ayırdıkları süreyi artırarak daha pasif bir dönem yaşadıkları düşünülmektedir.

Tablo 3. Bağımsız Değişkenlere göre FATÖ ve Alt Boyut Puanlarının Karşılaştırııması

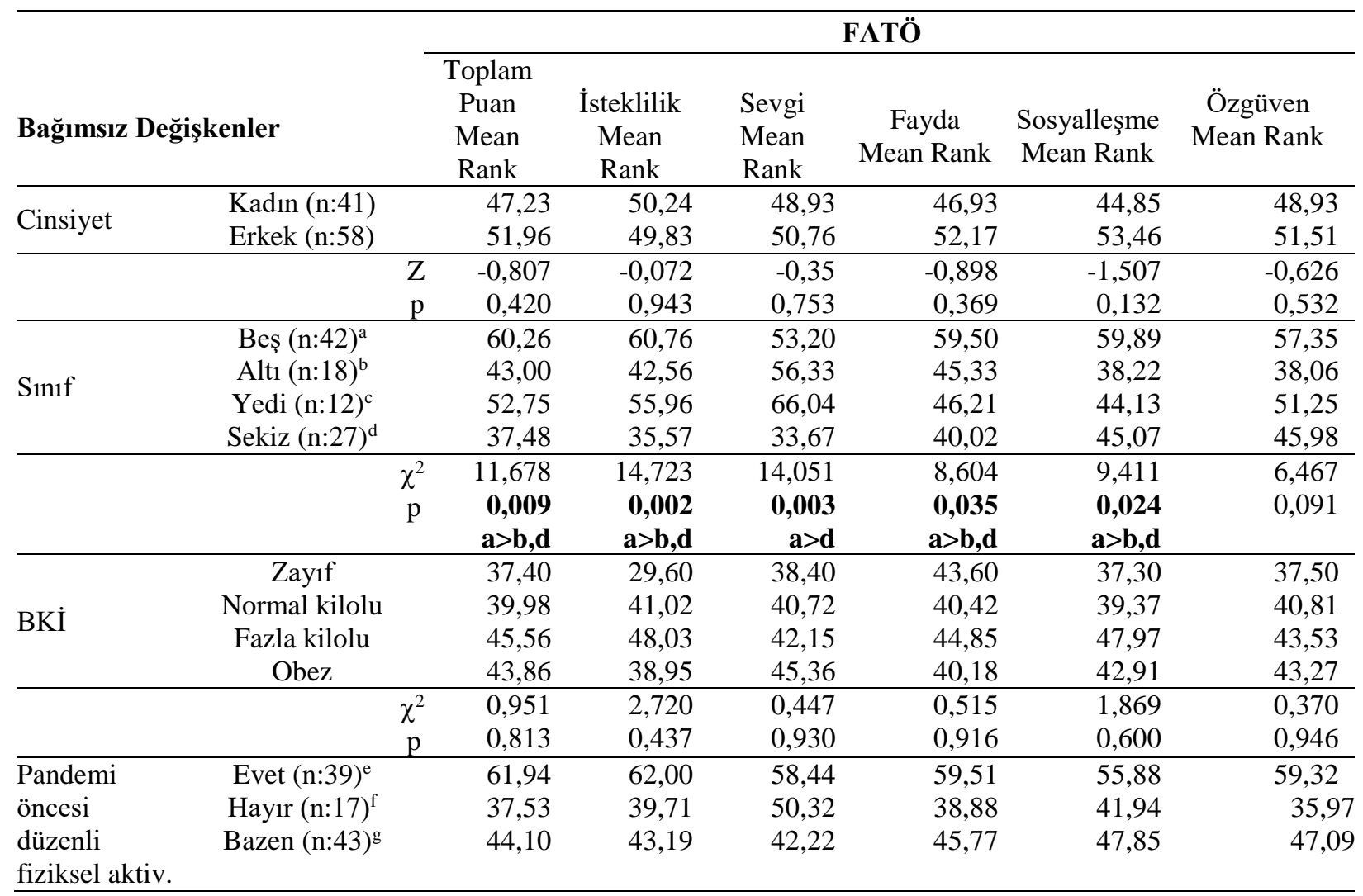


Tablo 3. (Devamı) Bağımsız Değişkenlere göre FATÖ ve Alt Boyut Puanlarının Karşılaştırılması

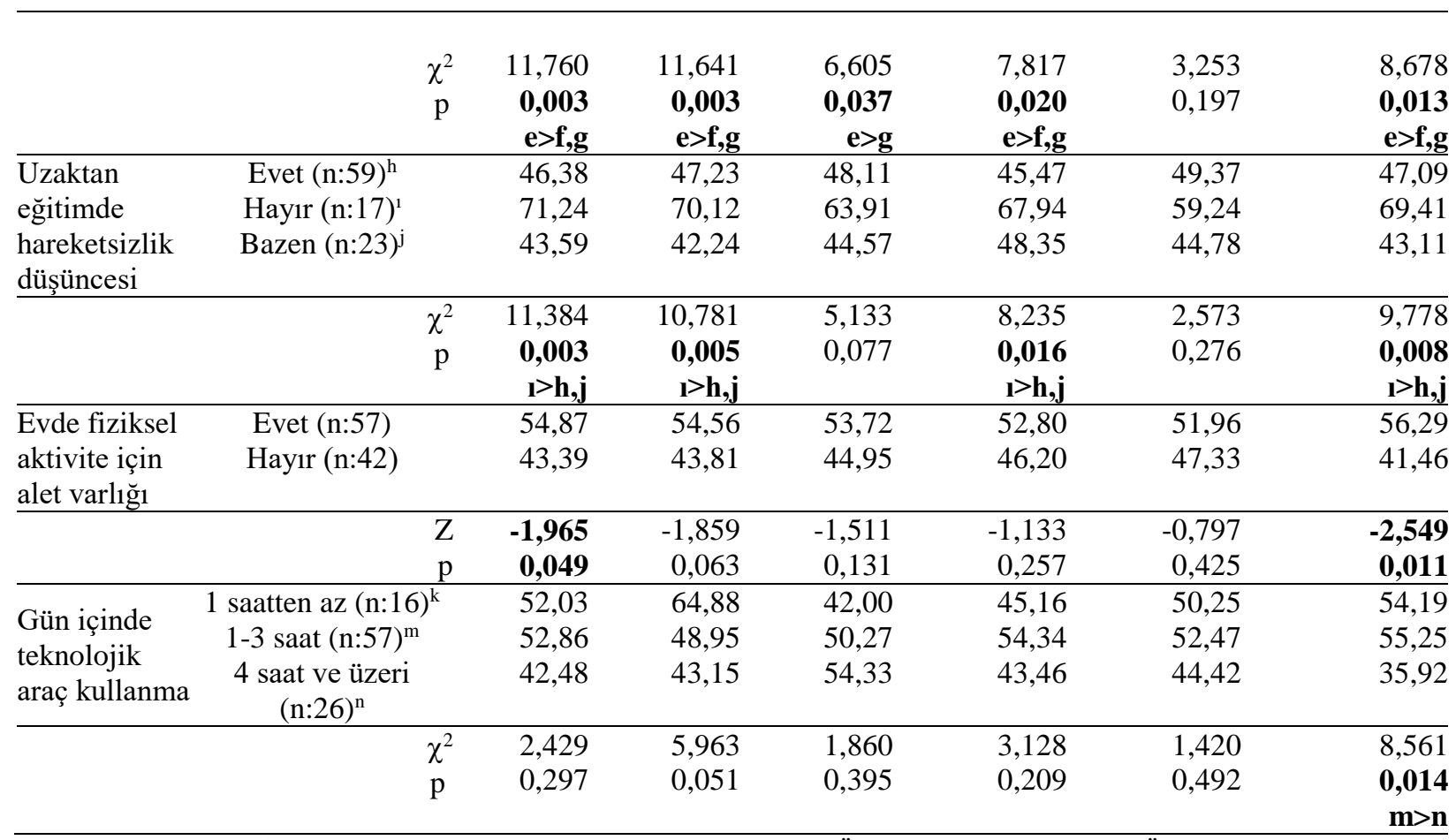

Z: MannWhitney U, $\chi^{2}$ : Kruskal Wallis, Mean Rank: Sıra ortalaması FATÖ: Fiziksel Aktivite Tutum Ölçeği

Stresle başa çıkma alt boyutlarının çalışmanın bağımsız değişkenlerine göre değerlendirmesi Tablo 4'te sunulmuştur. Buna göre kadınlarda duygusal kaçınmanın anlamlı olarak $(p=0,003)$ daha fazla kullanılmasi; etkin olmayan bir baş etme tarzı olduğu için kız öğrencilerin duyguları yönetmede zorluk yaşadıkları olarak yorumlanabilir. Bedel ve Güler'in pandemi öncesinde yaptığı çalışmada, cinsiyet değişkenine göre başa çıkma tarzlarında anlamlı fark bulunmamıştır. ${ }^{35} \mathrm{Bu}$ farklı sonuçların nedeni olarak pandemi döneminden $\mathrm{k} 1 \mathrm{z}$ öğrencilerin duygusal anlamda daha olumsuz etkilendikleri ve duygulardan kaçındıkları gösterilebilir. Beşinci sınıftaki öğrencilerin öfke/saldırganlık puanının diğer sınıflara göre daha düşük, aktif planlama ve diş yardım arama puan ortalamalarının altı ve sekizinci sinıflara göre daha yüksek olduğu belirlendi $(p<0,05)$. Sınıf düzeyi ve yaş arttıkça stresle etkin başa çıkmada problem yaşandığı ve dolayısıyla stres düzeyinin de yükselmesi olarak değerlendirilebilir. Taş'ın çalışması bu bulguyu ve düşünceyi desteklemektedir. ${ }^{26} \mathrm{Bu}$ durumun ortaokul son sınıf düzeyine yaklaştıkça liselere giriş genel sınavinın yol açtığı sınav stresi ile ilişkili olabileceği düşünülmektedir.

Bir saatten daha az teknolojik araç kullananlarda duygusal kaçma ve kabullenme puan ortalamaları düşükken, dört saatten fazla kullananlarda ise aktif planlama/problem çözme puan ortalaması anlamlı olarak düşük bulundu $(p<0,05)$. Stresle aktif planlama ve problem çözme becerilerini kullanarak etkin başa çıkamayan, stresli durumların yarattığ 1 duygularla etkin baş edebilmek yerine duygulardan kaçan öğrencilerin gün içinde teknolojik araçlara daha fazla zaman ayırdığı bulgusu dijital ortamlarda geçirilen sürenin öğrencilerin stresle başa çıkma sürecini olumsuz etkilediğini göstermektedir. Pandemi döneminde yaşanan stresin çocuklar üzerindeki olumsuz etkileri göz önünde bulundurulduğunda, stresle başa çıkma sürecine olumlu etki sağlayabilecek aktivitelere ihtiyaç olduğu düşünülmektedir. 
Tablo 4. Bağımsız Değişkenlere Göre ÇSBÖ Alt Boyut Puanlarının Karşılaştırılması

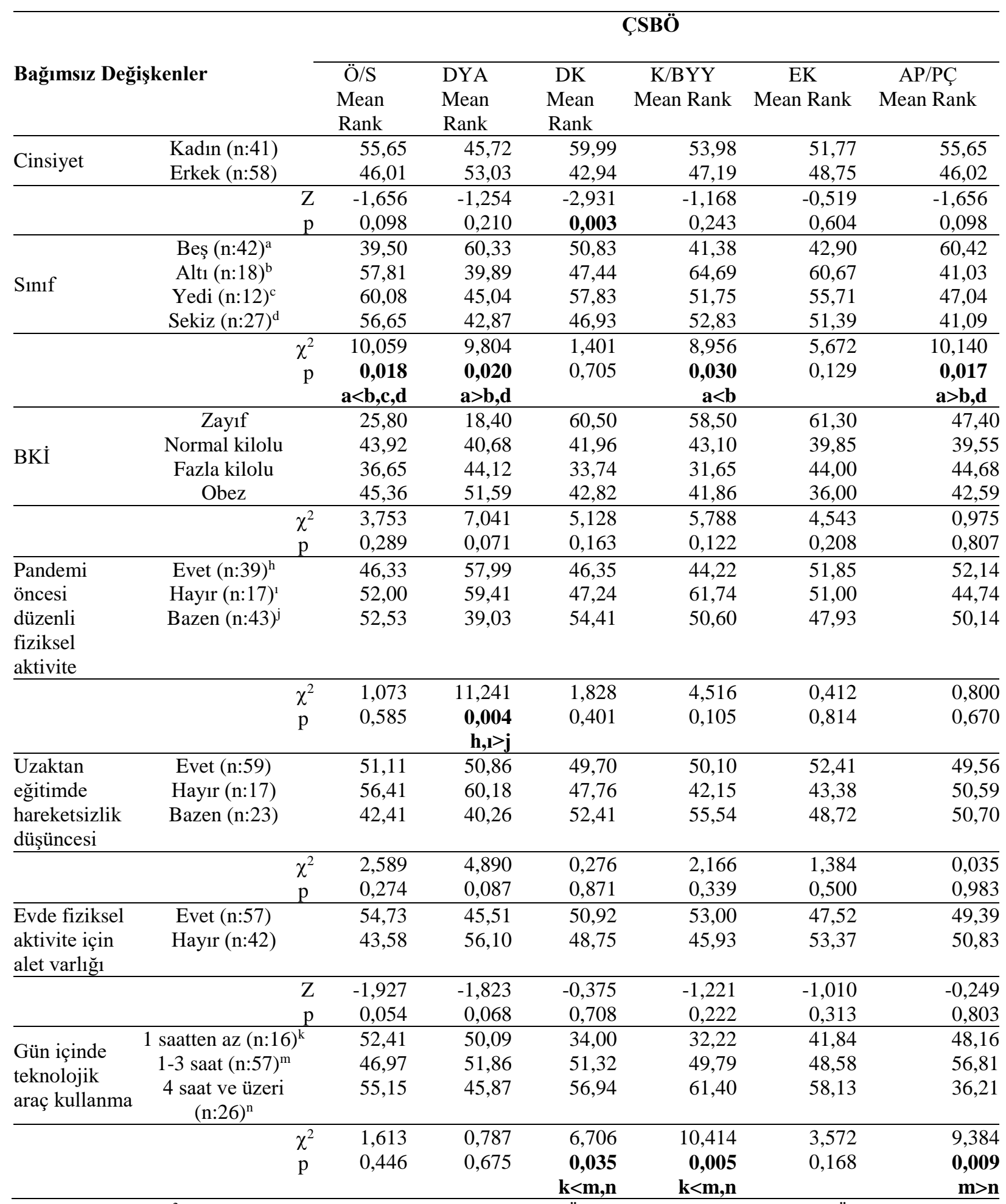

Z: MannWhitney U, $\chi^{2}$ : Kruskal Wallis, Mean Rank: Sıra ortalaması ÇSBÖ: Çocuklarda Stresle Başa Çıkma Ölçeği

Ö/S: Öfke/saldırganlık, DYA: Duygusal Yardım Arama, DK: Duygusal Kaçınma, K/BYY: Kabul/Bilişsel Yeniden Yapılandırma, EK: Eylemsel Kaçınma, AP/PÇ: Aktif Planlama/Problem Çözme

Öğrencilerin yaşı ile FATÖ genel toplam, isteklilik ve fayda alt boyutları ve ÇSBÖ alt boyutlarından dış yardım arama ve aktif planlama/problem çözme arasında negatif düzeyde, öfke/saldırganlık arasında ise pozitif düzeyde anlamlı ilişkiler saptandı. BKİ ortalaması ile fiziksel aktivite tutumu 
arasında anlamlı bir ilişki bulunmamışken, stresle baş etme tarzlarından sadece duygusal kaçma arasında negatif bir ilişki belirlendi (Tablo 5). Haftalık fiziksel aktivite saati ile sadece FATÖ genel toplam ve fayda alt boyutu arasında; stresle başa çıkma yollarından öfke/saldırganlık, duygusal ve eylemsel kaçma alt boyutları arasında anlamlı pozitif ilişki belirlendi (Tablo 5).

Elde edilen verilere göre pandemide stresle baş etmede fiziksel aktivitenin fayda sağlayacağı söylenebilir.

Tablo 5. Sürekli Değişkenler ile FATÖ ve ÇSBÖ Arasındaki Korelasyonlar

\begin{tabular}{|c|c|c|c|}
\hline & Yaş & $\begin{array}{c}\text { BKİ } \\
\text { rs }\end{array}$ & $\begin{array}{c}\text { Fiziksel aktiviteye ayrilan saat } \\
\text { (Saat/Hafta) } \\
\text { rs }\end{array}$ \\
\hline \multicolumn{4}{|l|}{ FATÖ ve Alt Boyutlar } \\
\hline Genel Toplam & $-0,230 *$ & 0,013 & $0,204 *$ \\
\hline İsteklilik & $-0,342 * *$ & $-0,012$ & 0,062 \\
\hline Sevgi & $-0,154$ & 0,052 & 0,187 \\
\hline Fayda & $-0,216 *$ & $-0,050$ & $0,273 * *$ \\
\hline Sosyalleşme & $-0,132$ & 0,099 & 0,081 \\
\hline Özgüven & $-0,069$ & 0,011 & 0,167 \\
\hline \multicolumn{4}{|l|}{ ÇSBÖ-Alt Boyutlar } \\
\hline Öke/Saldırganlık & $0,212 *$ & 0,097 & $\mathbf{0 , 3 5 3} * *$ \\
\hline Diș Yardım Arama & $-0,202 *$ & 0,179 & $-0,137$ \\
\hline Duygusal Kaçma & $-0,076$ & $-0,231 *$ & $0,293 * *$ \\
\hline Kabul/Bilişsel Yeniden Yapılandırma & 0,161 & $-0,103$ & $-0,006$ \\
\hline Eylemsel Kaçma & 0,134 & $-0,087$ & $0,278 * *$ \\
\hline Aktif Planlama/Problem Çözme & $-0,236 *$ & $-0,071$ & $-0,183$ \\
\hline
\end{tabular}

rs Spearmann Korelasyon Analizi, *: p<0,05, **: $p<0,01$ ÇSBÖ: Çocuklarda Stresle Başa Çıkma Ölçeği FATÖ: Fiziksel Aktivite Tutum Ölçeği

\section{Araştırmanın Kısıtlılıkları}

Araştırmanın tek ortaokulda yapılmış olması, bu sebeple örneklemdeki katılımcı sayısının düşüklüğü çalışmanın kısıtlılığını oluşturmaktadır.

\section{SONUÇ VE ÖNERILER}

$\mathrm{Bu}$ çalışmadan elde edilen verilere göre, katılımcı öğrencilerin FATÖ puan ortalamasının olumlu düzeyde olduğu, öğrencilerin büyük çoğunluğunun pandemi sürecinde hareketsizleştiğini düşündüğü, stresle başa çıkmada en yüksek puan ortalamasının dış yardım arama alt boyutunda, en düşük puan ortalamasının ise öfke/saldırganlık alt boyutunda olduğu belirlenmiştir. FATÖ genel toplam puan ve isteklilik, fayda, sosyalleşme, özgüven alt boyutları ile ÇSBÖ alt boyutlarından aktif planlama/problem çözme arasında pozitif yönlü bir ilişkinin olduğu, öfke/saldırganlık ve kabul/bilişsel yeniden yapılandırma ile isteklilik arasında negatif bir ilişkinin olduğu saptanmıştır.

Öğrencilerin yaşı, sınıf düzeyi, gün içinde teknolojik araçlara ayırdıkları süre, pandemi öncesi düzenli yapılan egzersize göre fiziksel aktivite tutumlarında ve stresle başetme tarzlarında gruplar arasında farlılıkların olduğu, BKİ'nin öğrencilerin fiziksel aktivite tutumlarını etkilemediği belirlenmiştir.

Buna göre, pandemi sürecinde öğrencilerin yaşadıkları stresle başa çıabilmelerinde fiziksel aktivite tutumunu olumlu etkileyecek girişimlerde bulunulmasının ve aktivite düzeyini yükseltecek açık havada uygun koşullarda 
ya da düzenli olarak ev içinde egzersizlerin planlanmasının önemli olduğu düşünülmektedir. Planlanan egzersizlerin stresle başa çıkma sürecine olumlu katk1 sağlayarak fiziksel aktiviteye tutumu pozitif etkileyeceği öngörülmektedir. $\mathrm{Bu}$ nedenle ortaokul öğrencilerinin stresle etkin başa çıkma süreçleri için fiziksel aktivite düzeyinin artırılması, stresle etkin başa çıkma konusunda eğitim ve uygulamaların yapılması önerilmektedir. Önerilen düzenlemelerin pandemide hareketsiz kaldığını düşünen, teknolojik araçlara fazla zaman ayıran ve özellikle sinava hazırlanan 8. sınıf öğrencileri için daha öncelikle ele alınması gerektiği açıkça görülmektedir.

KAYNAKLAR

1. World Health Organization (WHO). (2021). "Adolescent Health". Erişim adresi: https://www.who.int/health-topics/adolescenthealth\#tab=tab_1. (Erișim tarihi: 01.03.2021)

2. Blum, R.W, Mmari, K. and Moreau, C. (2017). "It Begins At 10: How Gender Expectations Shape Early Adolescence Around The World". Journal of Adolescent Health, 61 (4), 3-4.

3. Mulye, T.P, Park, M.J, Nelson C.D, Adams, S.H, Irwin C.E. and Brindis, CD. (2009). "Trends in Adolescent and Young Adult Health in the United States". Journal of Adolescent Health, 45 (1), 8-24.

4. Nelson, M.C, Story, M, Larson, N.I, Neumark-Sztainer, D. and Lytle, L.A. (2008). "Emerging Adulthood and College-Aged Youth: An Overlooked Age For WeightRelated Behavior Change". Obesity, 16 (10), 22052211

5. Bell, J.A, Hamer, M, Richmond, R.C, Timpson, N.J, Carslake, D. and Davey Smith, G. (2018). "Associations of Device-Measured Pa Across Adolescence With Metabolic Traits: Prospective Cohort Study”. PLoS Medicine, 15 (9), e1002649.

6. Belair, M, Kohen, D.E, Kingsbury, M. and Coleman, I. (2018). "Relationship between Leisure Time Physical Activity, Sedentary Behaviour and Symptoms of Depression and Anxiety: Evidence From a Populationbased Sample of Canadian Adolescents". BMJ Open, 8, https://doi.org/10.1136/bmjopen-2017021119.

7. Biddle, S.J, Ciaccioni, S, Thomas, G. and Vergeer, I. (2019). "Physical Activity and Mental Health in Children and Adolescents: An Updated Review of Reviews and An Analysis of Causality". Psychology of Sport and Exercise, 42, 146-55.

8. Cabre-Riera, A, Torrent, M, Donaire-Gonzalez, D, Vrijheid, M, Cardis, E. and Guxens, M. (2019). "Telecommunication Devices Use, Screen Time and Sleep in Adolescents". Environmental Research, 171, 341-347.

9. Kenney, E.L. and Gortmaker, S.L. (2017). "United States Adolescents' Television, Computer, Videogame, Smartphone, and Tablet Use: Associations With Sugary Drinks, Sleep, Physical Activity, and Obesity". The Journal of Pediatrics, 182, 144-149.

10. Elhai, J.D, Dvorak, R.D, Levine, J.C. and Hall, B.J. (2017). "Problematic Smartphone Use: A Conceptual Overview and Systematic Review of Relations With Anxiety and Depression Psychopathology". Journal of Affective Disorders, 207, 251-259.
11. Panova, T. and Lleras, A. (2016). "Avoidance or Boredom: Negative Mental Health Outcomes Associated With Use of Information and Communication Technologies Depend On Users' Motivations". Computers in Human Behavior, 58, 249258.

12. T.C. Sağlık Bakanlığı Halk Sağlığı Genel Müdürlüğü. (2021). "Covid-19 (Sars-Cov-2 Enfeksiyonu) Genel Bilgiler, Epidemiyoloji ve Tanı Rehberi Bilimsel Danısma Kurulu Calısması". Erisim adresi: https://covid19.saglik.gov.tr/Eklenti/39551/0/covid19re hberigenelbilgilerepidemiyolojivetanipdf.pdf. (Erișim tarihi: 01.03.2021).

13. World Health Organization (WHO) (2021'a). "Infection prevention and control (IPC) principles and procedures for COVID-19 vaccination activities". Erișim adresi: file:///C:/Users/user/Downloads/WHO2019-nCoV-vaccination-IPC-2021.1-eng.pdf. (Erişim tarihi: 01.03.2021)

14. Kumar, V, Chawla, N, Gupta, S. and Aanad, J. (2020). "Children Coping With Stress During Lockdown". International Journal of Current Research and Review, 12 (18), 167-172.

15. Türkiye Cumhuriyeti Millî Eğitim Bakanlığı, Öğretim Programları Daire Başkanlığı. (2020). "Salgın (Covid 19) Sonrası Okula Uyum Kılavuz ve Etkinlikler". Erişim adresi: https://ttkb.meb.gov.tr/www/salginsonrasi-okula-uyum-kilavuzu-ve-etkinlikler hazirlandi/ icerik/390. (Erişim tarihi: 01.03.2021).

16. Chen, P, Mao, L, Nassis, G.P, Harmer, P, Ainsworth, B.E. and Li, F. (2020). "Coronavirus Disease (COVID19): The Need to Maintain Regular Physical Activity While Taking Precautions". Journal of Sport and Health Science, 9 (2), 103-104.

17. VanKim, N.A. and Nelson, T.F. (2013). "Vigorous Physical Activity, Mental Health, Perceived Stress, and Socializing Among College Students". American Journal of Health Promotion, 28 (1), 7-15.

18. Garber, M.C. (2017). "Exercise As a Stress Coping Mechanism in a Pharmacy Student Population". American Journal of Pharmaceutical Education, 81 (3), 50.

19. Bates, L.C, Zieff, G, Stanford, K, Moore, J.B, Kerr, Z.Y, Hanson, ED. and Stoner, L. (2020). "COVID-19 Impact on Behaviors Across the 24-Hour Day in Children and Adolescents:Physical Activity, Sedentary Behavior, And Sleep". Children, 7 (9), 138.

20. Chen, P, Mao, L, Nassis, G.P, Harmer, P, Ainsworth, B and Li, F. (2020'a). "Returning Chinese School-Aged Children and Adolescents to Physical Activity in the 
Wake of COVID-19: Actions and Precautions". Journal of Sport and Health Science, 9 (4), 322-24.

21. Yildızer, G, Bilgin, E, Korur, E.N, Yüksel, Y. ve Demirhan, G. (2019). "Ortaokul Öğrencileri için Fiziksel Aktivite Tutum Ölçeğinin Geliștirilmesi”. Spor Bilimleri Dergisi, 30 (2), 63-73.

22. Özbay, Y, Dilek-Öğretir, A, İlhan, T. ve Erzen, G. (2009). "11-14 Yaş Özel Sağlık Bakım İhtiyacı Olan Cocuklar Üzerinde Yaşam Kalitesini Yükseltmeye Dayalı Disiplinler Arası Destek Eğitiminin (DADE) Etkililiğinin Araştırılması", (105K152 nolu Proje). Tübitak Yayınları.

23. Neyzi, O, Bundak, R, Gökçay, G, Günöz, H, Furman, A, Darendeliler, F. and Baş, F. (2015). "Reference Values for Weight, Height, Head Circumference, and Body Mass Index in Turkish Children". Journal of Clinical Research in Pediatric Endocrinology. 7 (4), 280-293.

24. Dong, H, Yang, F, Lu, X. and Hao, W. (2020) "Internet Addiction and Related Psychological Factors Among Children and Adolescents in China Uring the Coronavirus Disease 2019 (Covid-19) Epidemic". Frontiers in Psychiatry, 11, 00751.

25. Türk, F, Kul, A. and Kılınç, E. (2021). "DepressionAnxiety and Coping Strategies of Adolescents During the Covid-19 Pandemic". Turkish Journal of Education, 10 (2), 58-75.

26. Taş, R. (2019). Ortaokul Öğrencilerinde Sosyal Etkinliklere Katılma Durumu ile Stres Düzeyleri Arasındaki İlişkinin İncelenmesi. (Yüksek Lisans Tezi), Biruni Üniversitesi Eğitim Bilimleri Enstitüsü, İstanbul.

27. Deng, C.H, Wang, J.Q, Zhu, L.M, Liu, H.W, Guo, Y, Peng, X.H. and Xia, W. (2020). "Association of WebBased Physical Education With Mental Health of College Students in Wuhan During the Covid-19 Outbreak: Cross-Sectional Survey Study". Journal of Medical Internet Research, 22 (10), e21301.
28. Çubuk, A. (2019). Ortaokul Öğrencilerinin İnternet Bağımlılığı, Fiziksel Aktivite Düzeyleri ve Akademik Başarı Durumları Arasındaki İlişkinin İncelenmesi. (Yüksek Lisans Tezi), Marmara Üniversitesi Eğitim Bilimleri Enstitüsü, İstanbul.

29. Birgün, A, Özen, E, Uğraş, B.S. ve Pehlivan, B.S. (2020). "Ortaokul Öğrencilerinin Fiziksel Aktiviteye Tutum Düzeylerinin İncelenmesi”. Uluslararası Dağcılık ve Tırmanış Dergisi, 3 (2), 64-75

30. İnce Parpucu, T, Süzen, İ. ve Parpucu, H.Ş. (2021). "Otizm Spektrum Bozukluğu Olan Çocuklarda Covid19 Öncesi ve Sirasında Fiziksel Aktivite Seviyelerinin Karşılaştırılması”. 4-7 Şubat 2021, Isparta Otizm Kongresi (52-53), Isparta.

31. Lim, M.T.C, Ramamurthy, M.B, Aishworiya, R Rajgor, D.D, Tran, A.P, Hiriyur, P. and Goh, D.Y.T (2021). "School Closure During the Coronavirus Disease 2019 (Covid-19) Pandemic-Impact on Children's Sleep". Sleep Medicine, 78, 108-114.

32. Gülbetekin, E, Güven, E. ve Tuncel, O. (2021). "Adölesanların Dijital Oyun Bağımlılığı ile Fiziksel Aktivite Tutum ve Davranışlarını Etkileyen Faktörler”. Bağımlılık Dergisi, 22 (2), 148-160.

33. Orhan, E. (2018). 10-14 Yas Arasındaki Cocukların Fiziksel Aktivite Seviyesi, Dijital Oyun Bağımlılığı ve Dikkat Düzeyleri Arasındaki İlişkinin İncelenmesi. (Yüksek Lisans Tezi), Niğde Ömer Halisdemir Üniversitesi Sosyal Bilimler Enstitüsü, Niğde.

34. Hazar, Z, Tekkurşun Demir, G, Namlı, S. ve Türkeli, A. (2017). "Investigation of the Relationship between Digital Game Addiction and Physical Activity Levels of Secondary School Students". Niğde Üniversitesi Beden Eğitimi ve Spor Bilimleri Dergisi, 11 (3), 32032

35. Bedel, A. ve Güler, G. (2019). “Ortaokul Öğrencilerinin Psikolojik Sağlamlıklarının Başa Çıma Stratejileri Açısından İncelenmesi”. Akademik Bakıș Dergisi, 71, 157-169. 